\title{
Tecnicidades e Identidades Migrantes nos Usos Sociais das Mídias: Uma Aproximação à Diáspora Senegalesa no Sul do Brasil
}

\author{
Liliane Dutra Brignol ${ }^{1}$ \\ 'Professora do Programa de Pós-graduação em Comunicação do Departamento de Ciências da \\ Comunicação da Universidade Federal de Santa Maria (UFSM). Santa Maria, RS. Brasil. \\ E-mail: lilianebrignol@gmail.com

\section{INTRODUÇÃO}

$\mathrm{D}$ esde onde estudar os processos, as práticas e as apropriações dos meios de comunicação hoje em dia? Um ponto de partida possível e produtivo, no sentido proposto nesse artigo, é a dimensão das identidades e das diferenças, colocadas em contato de modo cada vez mais dinâmico (e muitas vezes conflitivo) a partir das migrações transnacionais. Especial atenção é dedicada à migração senegalesa para o Brasil nos últimos anos, da qual nos aproximamos pelo esforço de compreender como usos sociais de mídias digitais e em rede se conectam e atravessam experiências migrantes.

Em um contexto de diversidades, no qual temporalidades se entrecruzam em um mundo marcado por heterogeneidades, tal como nos provoca Ortiz (2015), os deslocamentos sociais, culturais e simbólicos que caracterizam as migrações exigem uma ruptura com sua compreensão baseada em uma lógica exclusivamente econômica ou securitária. É o que nos lembra Sayad (1998), em seu estudo clássico sobre as migrações como fato social total. Para além de suas implicações técnicas e da equação que busca equilibrar vantagens e custos sociais das populações migrantes, as migrações incluem dimensões jurídicas, políticas e sociais (Sayad, 1998:51), assim como culturais e comunicacionais, que precisam ser reconhecidas. 
Integrando deslocamentos entre territórios e fluxos comunicacionais, Martín-Barbero (2006; 2014) propõe pensar em duas categorias indicativas, de modos de ser e estar no mundo contemporâneo, muito mais próximas do que faz crer uma razão dualista. São elas os migrantes e os cibernautas (ou internautas), entendidos como sujeitos que indicam as múltiplas dinâmicas nas quais, segundo o autor, as urbanias e as cidadanias se entrelaçam. É o que percebemos ao identificar as mesclas entre as experiências e narrativas de ambos. Como nos lembra, são milhões de deslocados, dentro e fora de cada país, que praticam a cidade que habitam também pelos relatos que compartilham nas redes digitais (Martín-Barbero, 2015:27).

As pistas trazidas pelas dinâmicas dos migrantes e internautas ajudam a olhar a diversidade cultural: fonte de reflexão e problematização teórica em toda a trajetória de Martín-Barbero, e retomada como um dos principais pontos a tensionar a análise dos processos comunicacionais contemporâneos (Martín-Barbero e Berkin, 2017). Em seus textos mais recentes, o pesquisador, reconhecido como um cartógrafo mestiço (Martín-Barbero, 2002:10), trata de duas dinâmicas essenciais na transformação do lugar da cultura em nossas sociedades: a revitalização das identidades e a revolução das tecnicidades. Neste percurso, ao mesmo tempo que os processos de globalização convertem as identidades em protagonistas de conflitos internacionais, reconfiguram "a força e o sentido dos laços sociais e as possibilidades de convivência no nacional e no local" (Martín-Barbero, 2014:23-24).

Em outra perspectiva à qual nos aproximamos, Appadurai (2004) lembra do papel das mídias e das migrações enquanto sinais diacríticos e interligados de um momento de ruptura. Em seu exercício de compreensão sobre a configuração das dimensões culturais da globalização, o autor identifica ambas como marcas do mundo presente, forças que não são inéditas, mas que "parecem impelir (e, por vezes, compelir) a obra da imaginação" (Appadurai, 2004:15). Neste sentido, tanto cidadãos quanto imagens em deslocamento - e, portanto, fora das certezas dos limites locais - atuam profundamente na ressignificação da subjetividade moderna.

Este entrelaçamento entre migrações, mídias e redes é o que problematiza o projeto de pesquisa "Comunicação em rede, diferença e interculturalidade em redes sociais de migrantes senegaleses no Rio Grande do Sul"1. Trata-se de uma investigação sobre novos fluxos de 
migrações transnacionais para o Sul do Brasil, cujo objetivo foi investigar as redes sociais migratórias de senegaleses (com foco nos municípios de Porto Alegre, Caxias do Sul e Santa Maria) através de uma aproximação qualitativa às suas práticas e processos de comunicação, construídos entre usos sociais das mídias e comunicação interpessoal e intercultural. Nesse artigo, buscamos discutir como as mediações das identidades e tecnicidades atravessam as experiências migrantes de usos sociais das mídias, especialmente das mídias digitais e em rede. Para isso, partimos de uma contextualização sobre a migração senegalesa, seguida de revisão teórica sobre a perspectiva das mediações e a noção de identidades em diáspora, de modo a fundamentar a análise sobre apropriações midiáticas de senegaleses residentes no Rio Grande do Sul, entendidas em termos táticos. São, assim, observadas como práticas cotidianas caracterizadas pela ausência de um lugar próprio, marcadas pela astúcia do homem comum, em suas muitas maneiras de fazer (De Certeau, 2008). Às táticas, indisciplinadas por definição (Peixoto, 2018), nos voltamos para observar usos das mídias por migrantes desde a perspectiva das brechas e das pequenas subversões cotidianas, responsáveis por mobilidades, que são muitas vezes transgressoras e políticas (Peixoto, 2018:101).

As estratégias metodológicas da pesquisa são construídas a partir da inserção em um campo de investigação amplo, complexo e multissituado, uma vez que abarca dinâmicas de comunicação em rede que se constroem de modo transnacional (entre Brasil e Senegal). Essas redes de comunicação conectam os sujeitos migrantes em diferentes cidades (levando em conta as especificidades locais), e incluem práticas e processos de comunicação que se dão entre as instâncias online e offline. Entendemos que qualquer aproximação a estes contextos só pode ser feita a partir de um percurso que rompa com nacionalismos metodológicos ${ }^{2}$ (Beck, 2007) e que avance com a certeza de que estamos sempre tateando no escuro, para usar outra fecunda metáfora proposta por Martín-Barbero (2001).

O trabalho baseia-se na ideia de que a migração é um processo social que integra a história da humanidade, para o qual olhamos a partir das noções de transnacionalismo (Portes, 1997) e de redes migratórias (Truzzi, 2008). Considera os sujeitos migrantes para além de sua dimensão enquanto agentes econômicos, mas também a partir de fatores sociais e culturais que ajudam a entender as relações tecidas entre territórios, pertenças e reconhecimentos. 
Trata-se de um movimento de pensar as migrações não por seu caráter de excepcionalidade, diante de uma perspectiva que prioriza a permanência como o fenômeno normalmente esperado, conforme criticado por Hahn e Klute (2007). Isso exige afastamento, por exemplo, de uma discussão sociológica que enfatize as causas da migração a partir dos fatores de push and pull, por entender que as migrações configuram um fenômeno social particularmente complexo. Além disso, como alertam Hahn e Klute (2007:11), a perspectiva normativa dos movimentos migratórios como exceção, em comparação com modos de vida sedentários, contradiz a realidade de muitos povos e grupos - particularmente no continente africano.

O Brasil, que historicamente se constitui como um país marcado por distintos fluxos migratórios ${ }^{3}$, consolida-se como país de migração ao assumir posição de destaque e liderança na América Latina até a primeira década do século XXI. Isto é identificado por Patarra (2012) com base no aumento de autorizações de trabalho, no incremento no número de pedidos de refúgio e na ampliação do debate sobre políticas migratórias no contexto nacional - o que culminou com a aprovação de uma nova Lei de Migração (no 13.445/2017)4 . No entanto, esse movimento não significou a superação de uma perspectiva reducionista do fenômeno. Essa perspectiva é muitas vezes limitada à esfera da regulação econômica ou política e prioriza migrantes do Norte global (relacionados à ideia de migração qualificada) em detrimento de outros, como os coletivos senegaleses no Sul do Brasil. Cenário mais restritivo é percebido desde 2018, com o recrudescimento do discurso do governo federal em relação ao tema das migrações e das políticas sociais de modo geral.

\section{O CENÁRIO DA MIGRAÇÃO SENEGALESA NO RIO GRANDE DO SUL}

Os fluxos migratórios de senegaleses para o Brasil compõem dinâmicas complexas do cenário das migrações transnacionais no século XXI, marcadas por movimentos cada vez mais intensos entre países do Sul global. Segundo Baeninger, na última década, as migrações Sul-Sul demonstraram a complexidade e heterogeneidade da migração:

Denotam os desafios teórico-metodológicos para explicações e análises das migrações entre os países da região bem como da imigração haitiana, síria, africana, iraquiana, coreana, de imigrações qualificadas, de imigrações refugiadas, dentre outras modalidades migratórias que constroem o mosaico das tendências de deslocamentos de população na contemporaneidade (Baeninger, 2018:13). 
Conforme Uebel (2018), a partir da crise econômica de 2008, com a falência dos modelos de recepção e integração de migrantes e refugiados em países tradicionalmente receptores do Hemisfério Norte, novas alternativas se colocaram para os deslocamentos. Uma dessas opções foi o Brasil, que vivia à época um momento de projeção e crescimento econômico, bem como as nações da Bacia do Prata e da América Latina. Segundo dados oficiais analisados por Uebel, em nosso contexto regional, a migração senegalesa deu-se de maneira mais significativa primeiramente para a Bolívia em 2012, posteriormente para a Argentina em 2013, e só em 2014 o Brasil passou a registrar um ingresso migratório relevante (período em que se dá o início de nossa pesquisa) - muito embora já houvesse registro desta presença migratória menos expressiva desde 2010.

Marcada por "um fluxo rápido, intenso, chamativo (pelo menos por parte da mídia) e em constante transformação em um curto período de tempo, menos que uma década" (Uebel, 2018:177), a migração senegalesa ganhou contornos distintos com o agravamento da crise econômica no país. Isso levou à demissão de migrantes empregados formalmente e ampliou seu contingente de trabalhadores informais, sobretudo no comércio de mercadorias nas ruas de grandes e médias cidades. "Nesse sentido, o Brasil viu uma redução drástica na imigração dos senegaleses entre 2015 e 2016, ao contrário da Argentina, que apresenta desde o boom de 2013, um fluxo constante, sem tendências de diminuição" (Uebel, 2018:177).

Dentro do contexto escolhido para essa pesquisa, o Rio Grande do Sul, situado na fronteira com Uruguai e Argentina, sempre teve sua história marcada pela migração. Mais recentemente, a diversificação dos coletivos migrantes tem dinamizado as relações locais, mobilizado a atenção de pesquisadores e aparecido como tema de cobertura midiática. De acordo com uma reportagem da revista da Fundação de Economia e Estatística do RS (FEE) ${ }^{5}$, com base na Relação Anual de Informações Sociais (RAIS), o Estado teve aumento contínuo na mão de obra migrante com carteira assinada, saindo de 3.571 em 2010 para 10.781 em 2014. Embora este número contemple apenas a questão do trabalho formal, indica o crescimento da presença migratória de um modo geral. 
Entre as principais nacionalidades dos trabalhadores migrantes no Brasil durante 2014 e o primeiro semestre de 2015, segundo dados do Relatório Anual do Observatório das Migrações Internacionais - OBMigra (Cavalcanti et al., 2015), estavam a haitiana, seguida da senegalesa. O relatório indicava, ainda, que as admissões dos senegaleses foram majoritariamente concentradas em municípios do sul do país - especialmente do Rio Grande do Sul. No relatório de 2018, os senegaleses destacaram-se como a nacionalidade com mais autorizações concedidas pelo Conselho Nacional de Imigração (CNig), totalizando 2.285 pedidos (Cavalcanti et al., 2018). Isso demonstra a regularidade e a importância desse fluxo migratório para o estado.

Ainda na análise de dados do relatório OBMigra de 2015 (Cavalcanti et al., 2015) apontam que em 2014 a média salarial dos senegaleses foi de $\mathrm{R}$ \$960,00 no momento da admissão, destacando as seguintes atividades econômicas: abate de aves e suínos, construção de edifícios e restaurantes e outras atividades que exigem pouca qualificação. A maioria dos senegaleses admitidos em 2014 tinha nível de escolaridade fundamental (completo ou incompleto). Em 2018, o Rio Grande do Sul permaneceu como o estado que mais empregava senegaleses no mercado formal (843 de um total de 1.236 migrantes), sendo em sua maioria homens entre 20 a 39 anos (Cavalcanti, Oliveira e Macedo, 2018).

Este perfil aproxima-se do observado em pesquisas locais, como indicam Herédia e Pandolfi (2015). Com base em dados do Centro de Acolhimento ao Migrante (CAM) ${ }^{6}$, entre 2010 e 2014 foram cadastrados 1.856 senegaleses na cidade. Destes, 1.841 eram homens, majoritariamente entre 21 e 35 anos (77\%). Os dados indicam também que 50,97\% dos migrantes senegaleses em Caxias do Sul são solteiros, $24,41 \%$ possuem Ensino Fundamental incompleto e 15,09\% Ensino Fundamental completo, enquanto 13,25\% concluíram o Ensino Médio. Assim como Caxias do Sul, Porto Alegre e outros municípios, especialmente do norte gaúcho, destacam-se pela presença de migrantes senegaleses. Os migrantes senegaleses que escolhem o estado para viver são, principalmente, homens jovens em busca de oportunidades de trabalho. Nessa pesquisa, sobretudo através dos procedimentos de observação participante e de entrevistas com migrantes senegaleses, confirmou-se um perfil de sujeitos jovens, negros, entre 20 e 30 anos, na maioria homens com variados graus de escolaridade. Todos os entrevistados eram da etnia wolof, falantes prioritariamente de wolof, um dos idiomas do Senegal - além do francês, língua oficial e falada 
pelos migrantes escolarizados. Alguns também conheciam o árabe e já se comunicavam em português, com diferentes graus de conhecimento do idioma. Além disso, todos os migrantes com quem conversamos são muçulmanos, integram a confraria Mouride e participam de encontros e atividades religiosas.

Os três municípios ${ }^{7}$ foram escolhidos em função da presença do coletivo migrante, mais especialmente desde 2010, sobretudo em Caxias do Sul e na capital Porto Alegre, na qual o incremento da presença migratória de senegaleses é mais recente. O contexto de Santa Maria, localizada na região central do Estado, em que ainda é pequena a presença migratória, se deve em função da inserção da universidade em que se desenvolve a pesquisa. Somam-se a isso especificidades do trabalho de campo, tal como ser uma cidade com pequena presença de migrantes senegaleses, mas que conta com redes de apoio e realização de eventos religiosos e culturais.

Quanto ao contexto do país de nascimento dos migrantes, entendemos que a experiência da migração integra a própria constituição da história do Senegal: um país localizado na África Ocidental; com fronteiras delimitadas pelo Oceano Atlântico, Gâmbia, Mauritânia, Mali e Guiné-Bissau; cuja capital é a cidade de Dakar, a oeste do país; e tem a formação de seu estado nacional marcada por tentativas de integração regional (Mamadou, 2011). Atualmente, conta com uma população de cerca de 15 milhões de habitantes, o Senegal é marcado pela mobilidade geográfica, inicialmente interna e depois transnacional (Sakho, Diagne e Sambou, 2017). Essa mobilidade chega a constituir-se como um modo de vida que "faz parte de múltiplas estratégias racionalizadas e decididas no interior da família e provocadas por situações-limite vividas no interior do país" (Tedesco, 2017:178). Entre essas situações-limite destacam-se as crises econômicas e as secas. Neste sentido, o Senegal integra um contexto social no qual a mobilidade desempenha historicamente um papel estruturante:

[...] há sociedades africanas nas quais fluxos e refluxos de múltiplas naturezas têm profundidade histórica e estão estruturalmente enraizados, fornecendo, de maneira aparentemente paradoxal, um ingrediente importante para a consolidação de fronteiras (espaciais, étnicas, geracionais e de gênero) (Dias e Lobo, 2012:9-10). 
No contexto transnacional, a migração senegalesa, que antes tomava como direção preferencial a metrópole França, passou a se diversificar, ganhando destaque países como a Itália, a Espanha e os Estados Unidos. Como apontado, desde a crise econômica de 2008, também países da América do Sul, a exemplo de Argentina (Chevalier-Beaumel e Morales, 2012; Kleidermacher, 2013) e Brasil (Tedesco e Kleidermacher, 2017; Heredia, 2015), aparecem como destinos preferenciais. Como indicam Sakho et al. (2015:23), o Ministério dos Senegaleses no exterior estimava que entre 2 e 3 milhões de senegaleses residiam fora do país.

Os dados não explicam totalmente as motivações da migração, mas ajudam a entender esse fluxo migratório que é, sobretudo, econômico. Caracteriza-se como uma migração de trabalho que pode ser entendida a partir da organização de redes migratórias, atravessadas por pertencimentos culturais e religiosos centralizados nas confrarias islâmicas.

\section{IDENTIDADES EM DIÁSPORA E USOS SOCIAIS DAS MÍDIAS}

Em nossa trajetória de investigação, nos aproximamos da perspectiva interdisciplinar dos estudos culturais, tanto a partir de sua dimensão teórica quanto às suas premissas metodológicas. Da mesma maneira, buscamos ampliar o diálogo com outras abordagens que contribuem para o estudo. Teoricamente, pensar a comunicação em rede de migrantes senegaleses implica em refletir sobre a própria compreensão das migrações transnacionais como produtoras de sentidos de deslocamentos que vão além dos geográficos; mas implicam em processos de ressignificação simbólica através dos quais as identidades, as diversidades e as diferenças são colocadas em contato de maneira mais dinâmica e desafiadora.

Estes deslocamentos são problematizados a partir da noção de diáspora, por meio da qual é possível repensar os próprios sentidos das identidades. Segundo Hall (1996), as identidades não procedem em linha reta e ininterrupta, advindas de uma origem fixa. Elas devem ser pensadas sempre a partir de dois vetores: o da similaridade e continuidade; e o da diferença e ruptura (Hall, 1996:70).

Nesta perspectiva, a diáspora não pode ser entendida como sinônimo de migração, mas como uma metáfora explicativa para os múltiplos deslocamentos culturais, simbólicos e identitários construídos a partir 
das experiências transnacionais e transculturais. A diáspora afasta-se, assim, de seu sentido literal, ligado à ideia de dispersão forçada de povos causada por intolerância ou perseguição. E assume um caráter mais amplo e complexo, que permite trazer elementos para pensar identidades cada vez mais fluidas, marcadas pelo jogo das diferenças e pelo confronto entre um passado imaginado e um presente cada vez mais compartilhado (Hall, 2003).

A diáspora africana é ponto central desta compreensão na trajetória do pesquisador caribenho. Neste sentido, a experiência da diáspora, como pretendida por Hall, "não é definida por uma pureza ou essência, mas pelo reconhecimento de uma diversidade e heterogeneidade necessárias; por uma noção de identidade que vive com e através, não a despeito, da diferença; por hidridação" (Hall, 1996:75).

Assim também Gilroy $(2007,2012)$, ao apresentar a noção de Atlântico Negro, reflete sobre uma formação intercultural e transnacional que rompe com paradigmas nacionalistas, contrapondo e denunciando o racismo e o etnocentrismo. A diáspora é importante nessa discussão por apontar para um sentido mais híbrido e maleável de cultura e de identidades, sendo entendida pelo autor como uma ecologia social de identificação: "Como uma alternativa à metafísica da 'raça', da nação e da cultura delimitada e codificada no corpo, a diáspora é um conceito que problematiza a mecânica cultural e histórica do pertencimento" (Gilroy, 2007:151).

Pensar a diáspora senegalesa, na aproximação aos deslocamentos transnacionais contemporâneos em seus múltiplos sentidos e motivações, nos leva a analisar as redes de relações construídas entre o Brasil e a África também a partir de semelhanças, diferenças e solidariedades (Gilroy, 2007). É pensar, nos termos de Hall (1996, 2003), em identidades sempre inacabadas, como questões de "se tornar ou devir", mais do que como singularidades do ser.

Mesmo que a diáspora negra seja constitutiva do próprio sentido de Brasil e que muitas redes de relações conectem esses dois países (como as semelhanças humanas e naturais e a história compartilhada de colonialismo), a pesquisa confirmou, no contexto brasileiro, um profundo desconhecimento sobre o continente africano em geral (Visentini, Ribeiro e Pereira, 2014) e sobre o Senegal em particular. Esta percepção pode ser confirmada pelas representações estereotipadas construídas pela mídia sobre a migra- 
ção senegalesa e pelos sentidos compartilhados no senso comum, entendidos como negativos pelos migrantes entrevistados. Muitas vezes, é na tentativa de romper com as posições binárias em que são colocados, que migrantes senegaleses se apropriam de tecnologias das mídias visando construir outras narrativas sobre suas trajetórias e vivências de maneira a valorizar suas riquezas socioculturais e sua história.

Para compreender essas apropriações, de modo a problematizar as práticas e processos de comunicação dos migrantes, nos valemos da aproximação à perspectiva dos usos sociais das mídias. Nesta abordagem, Martín-Barbero (2001) propõe um deslocamento conceitual para estudar a comunicação a partir de sua dimensão cultural e contextual, rompendo com matrizes funcionalistas e ideologistas. Abre-se, assim, um novo horizonte de problemas que, desde a publicação de De los medios a las mediaciones (1987), vêm sendo complexificados a partir de análises sobre a natureza comunicativa da cultura e da compreensão dos receptores não como simples decodificadores de mensagens, mas enquanto sujeitos situados socialmente, historicamente e culturalmente.

O mapa das mediações proposto por Martín-Barbero, no seu contínuo esforço de analisar as relações constitutivas entre comunicação, cultura e política, ajuda a refletir sobre "novos sentidos do social e novos usos sociais dos meios" (2001:20). Ao estudar os modos de uso social das mídias como lugar de resistência (2002:186), o autor se vale da noção de táticas proposta por De Certeau (2008) para entender o domínio da técnica como terreno de luta das classes populares para se fazerem ouvir. Isto demanda olhar as tecnologias de comunicação em suas implicações culturais como mais do que conjuntos de aparatos fechados em si mesmos. Implica entendê-los a partir de seus múltiplos e contraditórios modos de acesso, de aquisição e de usos.

Esse artigo investiga os usos sociais das mídias, pelos migrantes senegaleses, a partir das mediações das identidades e tecnicidades. Como discorre Martín-Barbero (2014:25): “é o próprio lugar da cultura na sociedade que muda quando a mediação tecnológica da comunicação deixa de ser meramente instrumental para espessar-se, adensar-se e converter-se em estrutura".

Trata-se de uma abordagem que busca identificar os modos de uso das tecnologias não apenas como dominação, mas também como forma de resistência, em um deslocamento do olhar da técnica em si para suas lógi- 
cas de apropriação, sobretudo pelas classes populares. Embora parta do pressuposto de uma inevitável subalternidade diante das lógicas impostas pela ordem tecnológica, a perspectiva dos usos sociais das mídias permite complexificar o estudo da comunicação, pois exige levar em conta as mediações implicadas nas relações entre sujeitos e tecnologias.

$\mathrm{O}$ avanço das tecnologias digitais e sua forte presença na experiência migratória transacional (Cogo, ElHajji e Huertas, 2012) abrem espaços para a construção de narrativas vindas dos próprios sujeitos, que, por sua vez, colocam em circulação questões referentes às identidades contemporâneas. Percebemos que o uso das tecnologias das mídias no contexto migratório, a partir do transnacionalismo, permite o estabelecimento de vínculos, conexões e interações que transcendem os limites territoriais. Neste sentido, estudar as dinâmicas de comunicação em rede de coletivos migrantes requer pensar a tecnologia não só como novidade dos aparatos, mas como novos modos de percepção e de linguagem, novas sensibilidades e escrituras (Martín-Barbero, 2014).

Apesar dos limites tecnológicos e das desigualdades sociais e econômicas enfrentadas no contexto das migrações, a diversidade nas apropriações das tecnologias por migrantes nos indica que tais usos são demandados por experiências identitárias e integram estas próprias experiências. A condição migrante ajuda a produzir modalidades particulares de usos midiáticos centrados, sobretudo nas relações com o país de nascimento e na criação de redes de partilha e convivência entre migrantes que compartilham experiências comuns de deslocamento (Brignol, 2010; Cogo, Gutiérrez e Huertas, 2008).

\section{CONSTRUÇÃO DO PERCURSO METODOLÓGICO}

Este estudo aproximou-se das redes migratórias de senegaleses através de uma combinação de procedimentos menos diretivos, incluindo a reflexividade dos pesquisadores aliada à observação prolongada e à escuta de relatos dos sujeitos pesquisados (Guber, 2001). Esse esforço de encontro com os sujeitos e suas experiências busca construir relações que rompam com a construção de estereótipos que levam a uma exotização da experiência migratória (Morales e Kleidermacher, 2015) - representada ora como problema, ameaça e perigo; ora como marcação da diferença a partir de seus aspectos folclóricos. 
Buscamos conhecer, através das técnicas da observação simples, observação participante, de conversas informais e entrevistas semiestruturadas (Gil, 2008), o contexto das redes sociais migratórias de senegaleses no RS. A observação simples e a observação participante partiram da aproximação com entidades de apoio às migrações no Estado, como o Cibai-Migrações ${ }^{8}$, o Fórum Permanente de Mobilidade Humana do RS $^{9}$ e o Centro de Apoio às Migrações (CAM). Integram as observações as próprias entidades migrantes, como as associações e as dahiras (casas que reúnem membros da confraria Mouride) dos senegaleses em Caxias do Sul e em Porto Alegre. Essas associações são responsáveis por dinâmicas identificadas em outras localidades marcadas pela presença migratória senegalesa, constituindo uma complexidade das relações sócio-materiais entre os senegaleses percebidas também em outras localidades - a exemplo do relatado por Heil (2018), ao identificar o papel destas associações na configuração de uma infraestrutura de chegada no contexto específico do Rio de Janeiro.

Em um trabalho de campo multissituado e que integra as ambiências online e offline, realizado entre 2014 e 2017, procuramos conhecer as dinâmicas de redes de migrantes senegaleses em suas práticas associativas, como reuniões, encontros, mobilizações, festas e atividades religiosas. Este processo também se deu pelo acompanhamento da diáspora senegalesa através das redes sociais online, em páginas, comunidades e perfis no Facebook e outras redes sociais online, através das quais pudemos acompanhar e participar de atividades organizadas pelos coletivos migrantes ${ }^{10}$.

Alguns contatos com migrantes que, por seu envolvimento como presidentes de associações ou como líderes locais foram colaboradores privilegiados na pesquisa, também se deram inicialmente através das redes sociais online, ou em encontros sobre a temática das migrações como o Seminário do Fórum Permanente de Mobilidade Humana do $\mathrm{RS}$, realizado anualmente em Porto Alegre.

Partindo dessa observação, procuramos identificar práticas comunicativas dos senegaleses, em usos sociais da mídia, através de apropriações e produções em sites, redes sociais online, vídeos e outras publicações diversas. Tentamos identificar também seus processos de comunicação em reuniões, encontros, mobilizações, festas e atividades religiosas. Já a observação e as conversas informais se deram nas cidades com presença do coletivo migratório, sobretudo Caxias do Sul e Porto Alegre, e em atividades promovidas pelos coletivos migrantes. 
Além de conversas informais, foram realizadas 14 entrevistas semiestruturadas que propunham conhecer, por meio das narrativas dos migrantes, questões relacionadas aos usos sociais das mídias e às dinâmicas de comunicação em rede, em suas relações com aspectos identitários e interculturais (Grimson, 2001). Entre os entrevistados aparecem líderes e coordenadores das associações formais e de redes informais, além de migrantes com perfis e trajetórias de migração distintas (quanto à idade, ocupação e tempo de migração).

Embora a intersecção de marcadores sociais da diferença (Moutinho, 2014) - como classe, raça, gênero, sexualidade e condição migratória seja fundamental para entender como os migrantes são posicionados nos contextos locais para os quais migram e como conseguem negociar essas posições, não explorar de forma aprofundada todos esses elementos. As relações de gênero, por exemplo, foram pouco exploradas na pesquisa, de maneira que boa parte das observações da análise está restrita à interação com migrantes do sexo masculino em idade laboral - o que reflete uma característica deste fluxo migratório.

Identificamos que o número de mulheres senegalesas que migram ainda é pouco expressivo, como também observaram Herédia e Gonçalves (2017) em relação à Caxias do Sul. Nessa cidade, embora a migração não seja apenas masculina, há uma presença bem menor no número de mulheres migrantes. "A saída da mulher da sociedade de origem é bem mais difícil do que a do homem, principalmente quando analisada pelo aspecto cultural", consideram (Herédia e Gonçalves, 2017:11).

De acordo com Sakho (2015, apud Herédia e Gonçalves, 2017), o aumento da participação feminina nos fluxos migratórios do Senegal para o exterior está vinculado aos processos de urbanização, de inserção no mercado de trabalho e de escolarização.

Essa passagem de uma estrutura familiar assentada sobre uma tradição rural foi fortemente impactada pelo crescente êxodo rural que vai modificando as dinâmicas familiares nas quais as mulheres passam também a desempenhar o papel de provedoras de seus núcleos familiares, afirmam (Herédia e Gonçalves, 2017:11).

Entretanto, isso não foi o observado em nossa pesquisa. 


\section{UMA APROXIMAÇÃO AOS USOS SOCIAIS DAS MÍDIAS POR MIGRANTES SENEGALESES}

As entrevistas e a observação participante das atividades promovidas pelos migrantes evidenciam a importância atribuída pelos senegaleses às apropriações do smartphone como forma principal de conexão à internet, destacando-se o uso de aplicativos para troca de mensagens instantâneas, como Whatsapp, Viber e Emo. A manutenção dos vínculos informativos e afetivos com familiares e amigos que permanecem no Senegal se dá prioritariamente por estas ferramentas, como verificado por Brignol (2015).

A rede social online mais usada pelos entrevistados é o Facebook, plataforma também adotada para a construção de páginas dos coletivos a que estão vinculados, como as associações de migrantes e grupos religiosos. A televisão aparece em menor escala nas entrevistas como referência no consumo de mídia, sendo lembrada como meio para audiência de futebol (citado como esporte preferido dos entrevistados, que costumam acompanhar partidas e torcer por times brasileiros) e, em menos casos, de filmes.

Durante as celebrações religiosas e eventos festivos a presença do celular é constante, e suas fotos e vídeos são compartilhados nos perfis de redes sociais online dos migrantes em tempo real. Também foi observada uma produção de conteúdo organizada em torno de mídias especializadas criadas e mantidas pelos próprios senegaleses, conectadas a outras páginas semelhantes e com uma produção em rede envolvendo coletivos de diferentes cidades brasileiras e de outros países com presença migratória senegalesa. No geral, foi constatada a importância das mídias digitais e das tecnologias móveis para os sujeitos, embora parte dos entrevistados tenha relatado também possuir computador pessoal, mas usá-lo menos do que o celular para se conectarem à internet.

Entendemos, assim, que as apropriações táticas das tecnologias integram a própria dinâmica diaspórica e ajudam a configurar as experiências dos migrantes senegaleses em suas culturas migratórias (Kandel e Massey, 2002; Hahn e Klute, 2007) - atuam na interação entre os migrantes, seus interlocutores que permanecem em seus países de nascimento e as comunidades dos locais onde estão estabelecidos. Como sugerido por Hahn e Klute (2007), as várias culturas migrató- 
rias - sempre dinâmicas e entendidas enquanto um conceito aberto que considera os significados atribuídos pelos próprios atores - são estabelecidas em negociações e conflitos entre os próprios migrantes e com outros grupos com os quais se relacionam.

Essa perspectiva aproxima-se daquela que propomos com base na noção de diáspora. Enfatiza uma abordagem relacional e suas implicações em dinâmicas complexas e de constantes tensionamentos entre continuidades e rupturas, similaridades e diferenças (Hall, 1996). As dinâmicas construídas a partir de usos sociais das mídias, por migrantes senegaleses, são analisadas a seguir levando-se em conta um conjunto de percepções construídas com base na análise dos relatos e das observações obtidas no trabalho de campo.

Vale destacar, ainda, que as reflexões aqui tecidas se deram segundo alguns sentidos comuns observados nas apropriações das tecnologias das mídias pelos migrantes que colaboraram com a pesquisa, de forma que não busca formular uma tipologia de usos que possa ser aplicada a outros casos sem a devida consideração sobre questões estruturais e contextuais específicas.

\section{FAMÍLIAS E RELAÇÕES TRANSNACIONAIS}

No caso dos senegaleses, a migração raras vezes aparece como um projeto individual. Trata-se de uma alternativa econômica diante da falta de empregos no Senegal e de um projeto que combina expectativas pessoais e familiares ligadas à história de exploração colonial do país. Segundo Kleidermacher (2013), os deslocamentos foram estimulados no Senegal como parte da ação colonizadora francesa, que ajudou a construir uma ideia de que o progresso e a educação deveriam ser obtidos fora do país - sobretudo na metrópole.

O desejo de migrar é parte das trajetórias dos senegaleses entrevistados, sendo comum a referência a outros parentes migrantes. Esse processo se deu inicialmente, e em maior medida, para a França; posteriormente, em direção à Espanha, Itália, e aos Estados Unidos; e mais recentemente para países da América do Sul. Esta constatação confirma a afirmação de Fall (apud Sakho, et al., 2015:29) de 
que "a migração laboral senegalesa foi originalmente influenciada e organizada pela colonização tanto na escolha dos destinos como na estrutura organizacional".

Nessa estrutura organizacional das migrações, muitas vezes as famílias tentam criar uma corrente migratória para seus filhos a partir de um financiamento inicial que garante a viagem e as condições para a instalação no novo país (Sakho, et al., 2015). Como explica Kleidermacher (2013), a flexibilidade e a mobilidade são vantajosas para a família, que passa a contar com o envio regular de valores em dinheiro por parte dos filhos, incrementando sua renda e/ou garantindo o sustento familiar.

Entre as principais motivações dos entrevistados para migrar aparecem, justamente, a busca por melhores condições de trabalho e a possibilidade de envio de dinheiro para parentes no Senegal, em dinâmicas de famílias ampliadas que reconfiguram vínculos no contexto transnacional. Essas famílias são constituídas, no caso de nossos entrevistados solteiros, pelas famílias de seus pais, incluindo tios, primos e outros parentes, ou pela esposa e filhos, no caso dos entrevistados casados.

As remessas podem ser entendidas como responsáveis pela manutenção de vínculos familiares e de uma comunicação constante e ininterrupta entre lá e cá, em uma dinâmica transnacional que pode atuar tanto no sentido de desenvolvimento econômico, como de dependência. Pode até mesmo representar certo peso, diante da obrigação assumida na vida dos jovens migrantes, como relata Kleidermacher (2013) sobre o caso dos entrevistados na Argentina.

Nessa abordagem, as remessas ultrapassam uma visão economicista sobre as migrações, pois ajudam a configurar um espaço transnacional mediado pelas tecnologias das mídias e que atuam na configuração de um contexto mais complexo de vínculos entre o país de nascimento e de migração dos sujeitos, integrando as próprias culturas migratórias e complexificando as múltiplas motivações para partir.

Além da obrigação dos envios de recursos financeiros, compreendemos um pouco mais sobre as dinâmicas das famílias transnacionais (Herrera, 2004; Pedone, 2007) para os migrantes senegaleses em seus relatos e na observação de suas práticas de comunicação. Em todos os casos, o contato com os familiares e amigos no Senegal aparece como 
principal uso da internet. Em mais de uma entrevista, por exemplo, o entrevistado interrompeu a gravação para atender a uma ligação (através de aplicativos de mensagens e chamadas de voz) de algum familiar no Senegal. Um dos entrevistados casados relatou que paga a conta de internet da esposa, que mora no Senegal, para garantir que os dois tenham uma comunicação mais rápida e contínua.

Como exemplo emblemático, um dos locais que marca a presença senegalesa em Caxias do Sul e que ajuda na manutenção das relações transnacionais é uma empresa, de propriedade de um dos entrevistados, que oferece chamadas telefônicas internacionais ${ }^{11}$. A loja funciona como ponto de encontro dos migrantes, em uma galeria no centro da cidade, e configura-se como um espaço social transnacional (Peñaranda Cólera, 2005). A Telefônica Touba é amplamente apropriada pelos migrantes, possui fortes referências étnicas e identitárias. E oferece a possibilidade de configuração de relações tanto com o espaço social na cidade de Caxias do Sul, quanto com o próprio Senegal. Desta forma, ajuda fortemente a redefinir estas relações.

A partir destas observações empíricas, pudemos perceber a importância de usos sociais das mídias para dinâmicas de comunicação em rede em garantir a manutenção de relações sociais e afetivas. Isso se dá especialmente em famílias transnacionais, que atuam como organizações sociais que permitem a vinculação simbólica simultânea a diferentes territórios através da mediação tecnológica, configurando laços mantidos e, algumas vezes, reforçados por meio de interações à distância.

\section{REDES DE APOIO INTRA E INTERCULTURAIS}

A comunicação pela internet também garante o contato com parentes ou conhecidos que já migraram, oferecendo aos sujeitos apoio no momento de inserção inicial no Brasil. Entre os entrevistados, a maioria já tinha algum familiar ou amigo residindo no país. Em outros casos, relataram contar com o apoio de algum conhecido no momento da chegada (mesmo que para isso tivessem apenas um nome, um número de telefone e a indicação de uma cidade). Durante uma das entrevistas, o entrevistado mostrou o telefone celular como primeiro objeto que adquiriu no Brasil: presente de um amigo que vivia há mais tempo no país. O objeto representava a segurança de manter conexão e contato com sua rede migratória. 
De modo geral, percebemos a importância das redes de apoio na organização da dinâmica migratória senegalesa não apenas em suas chegadas ao Brasil, mas também em suas rotinas cotidianas, o que ajuda a explicar a concentração de migrantes desta nacionalidade em algumas cidades. Aliada à existência de oferta de empregos, Caxias do Sul, por exemplo, destaca-se por ser uma das primeiras cidades brasileiras a organizar uma associação de migrantes senegaleses. Essa associação contava com uma casa de passagem para os migrantes recém-chegados que não tinham condições de alugar um local para morar, como parte de complexas infraestruturas de chegada (Heil, 2018).

As redes de apoio também são configuradas por relações informais entre amigos e conhecidos que trocam informações sobre os contextos locais, compartilham ofertas de emprego e facilitam o acesso à moradia (quase sempre compartilhada entre vários outros migrantes, em função dos altos custos e das burocracias que dificultam a locação). Para isso, além da comunicação presencial, a comunicação mediada torna-se essencial. Nota-se que as redes de apoio são ampliadas e ressignificadas a partir das conexões nos perfis e páginas em sites de redes sociais, especialmente no Facebook. Foi comum que, logo depois de um contato inicial, os entrevistados nos adicionassem em seus perfis ou solicitassem um número de telefone para comunicação por Whatsapp. Passávamos a integrar também suas redes de contatos no país e, muitas vezes, nos valemos dessa conexão para ampliar as interações iniciadas nas conversas informais, marcar entrevistas ou tirar dúvidas sobre alguma informação fornecida.

A exemplo do que identificaram Aparicio e Tornos (2005) e Páscual de Sáns (2007), a respeito do contexto espanhol, entendemos que as redes migratórias no caso dos migrantes senegaleses no RS também são constituídas por um conjunto de laços que conectam migrantes e não migrantes e que oferecem recursos que facilitam as relações no local para o qual migraram. Essas redes atuam tanto na conformação de dinâmicas intraculturais, instituindo um sentido de coletividade entre os próprios migrantes, quanto interculturais, através da construção de uma série de espaços comunicativos e de um conjunto de práticas que aproximam migrantes e não migrantes. 


\section{ASSOCIATIVISMO MIGRANTE}

Como comentado, as associações de migrantes integram as redes de apoio ao fenômeno migratório no contexto brasileiro. De modo geral, o associativismo é uma prática ligada ao fenômeno migratório (Cogo, 2012). As associações (assim como clubes, ONGs, grupos culturais, movimentos sociais, entidades confessionais etc.) atuam como parte das redes de apoio à migração e integram em torno da experiência migratória movimentos coletivos de caráter diverso. No caso dos senegaleses, identificamos associações nas cidades de Caxias do Sul, Porto Alegre e Passo Fundo, assim como outras em processo de organização. Todas criadas e geridas pelos migrantes.

Entre as principais dificuldades enfrentadas pelos senegaleses no Rio Grande do Sul, segundo entrevista concedida pelo presidente da Associação dos Senegaleses de Porto Alegre, estão barreiras linguísticas, com a dificuldade de compreensão e comunicação em português; a falta de moradia e os problemas com a burocracia imobiliária para locação de imóveis; os limites impostos pelas políticas migratórias que impedem a regulamentação dos senegaleses (a maioria aguardava a avaliação de pedido de refúgio); a mudança no cenário econômico, com o aumento do desemprego atingindo fortemente a população migrante, já precarizada no mercado de trabalho; e os entraves para a revalidação de diplomas, que impedem os sujeitos escolarizados e com formação profissional especializada de ocupar melhores postos de trabalho.

As associações atuam no enfrentamento dessas questões, de maneira organizada e coletiva, e assumem um lugar importante de representatividade migrante. Segundo o presidente da Associação dos Senegaleses de Caxias do Sul, as associações servem como local de encontro, troca de experiências, compartilhamento de desafios, fortalecimento de parcerias, e ampliam o convívio e a integração com a cidade em que estão inseridos. Para isso, costumam ser promovidas festas, encontros, eventos culturais e atividades religiosas, por vezes abertos à participação da população não migrante.

Nesse processo, mais do que uma apropriação utilitária das tecnologias das mídias pelas associações, percebemos como as lógicas comunicacionais são constitutivas das próprias entidades - que existem enquanto pontos de contato, encontro e reconhecimento para os migrantes. Assim, também ganham sustentação e visibilidade a partir de páginas em redes 
sociais online seguidas não apenas por senegaleses, mas também por brasileiros e migrantes de outras nacionalidades. As páginas no Facebook ajudam a divulgar as ações das associações, convidam para as atividades promovidas, oferecem espaço para discussão das demandas dos coletivos e promovem aproximação com as comunidades locais. As publicações costumam ser feitas em wolof e com eventuais traduções para o português ou francês, demonstrando a intenção de estabelecer diálogos para além dos limites do próprio coletivo.

Assim, o associativismo consolida-se como elo importante, na disputa pela construção de outros sentidos sobre as migrações, também nas mídias hegemônicas e em espaços institucionais, quando seus representantes são chamados a dar entrevistas, a participar de eventos, promover palestras e intermediar relações entre trabalhadores migrantes em empresas, por exemplo.

\section{VIVÊNCIA RELIGIOSA TRANSNACIONAL}

Observamos que a dimensão religiosa e transnacional é de suma importância na experiência da diáspora senegalesa. Isso é refletido nos usos sociais das mídias por esses migrantes no Rio Grande do Sul. A migração perpassa a questão laboral e religiosa muito fortemente, sendo possível observar vínculos e formação de redes entre senegaleses que, em função das dinâmicas e experiências ligadas à confraria Mouride $^{12}$, são atravessadas pela mediação religiosa. Como explica Moreno Maestro (2006), os membros das confrarias senegalesas acordam votos de obediência aos seus marabús/marabutos (líderes espirituais), considerados herdeiros do baraka (tolerância divina).

As vivências religiosas dos migrantes senegaleses já foram ricamente exploradas por Maestro (2006), Romero (2017), Rossa (2017), Césaro e Zanini (2017) e Brignol e Costa (2018). São indicados aqui apenas alguns elementos que ajudam a entender a relação entre as celebrações religiosas e a apropriação das tecnologias em rede. É o que percebemos na produção e compartilhamento de conteúdo sobre o mouridismo nos perfis e páginas de redes sociais online, na circulação de imagens de Cheikh Amadou Bamba e na transmissão em tempo real das atividades religiosas ${ }^{13}$, acompanhadas por outros senegaleses em diferentes partes do mundo - o que demonstra a dimensão transacional da fé entre os senegaleses mourides. Ao mesmo tempo, a webdiáspora ${ }^{14}$ senegalesa e a produção midiática em canais próprios de comunicação permitem 
expandir os sentidos da fé. Enquanto são compartilhadas mensagens, fotografias, vídeos e outros conteúdos produzidos sobre a mesma celebração, cria-se uma rede de experiências migratórias e religiosas, que fazem circular diferentes vivências por meio da rede, fomentam canais pessoais e coletivos e ajudam a construir novos sentidos da diáspora.

\section{EMPREENDEDORISMO SOCIAL E CULTURAL}

Três dos entrevistados são proprietários de microempresas e consideram-se empreendedores. Um deles é dono de uma gráfica e presta serviços de design, profissão que já exercia no Senegal; outro, possui a já referida empresa de chamadas telefônicas internacionais; e o terceiro é dono de uma microempresa individual de conserto de telefones celulares.

A pesquisa também acompanhou o surgimento de outros negócios ou empreendimentos étnicos (Halter, 2007; Garcés, 2011; Solé e Parella, 2005). Segundo Garcés (2011), a noção de economia étnica remete à existência de uma atividade econômica em que os proprietários dos negócios pertencem a um grupo específico ou coletivo étnico ou cultural, dirigindo-se, muitas vezes, também para uma clientela composta pelo mesmo grupo de referência. Halter (2007) identifica esta experiência de inserção econômica ao se referir a migrantes recentes, que enfrentam barreiras linguísticas ou se veem impossibilitados de atuar em sua área de formação.

Para estes migrantes que estão, portanto, "afastados do mercado de trabalho secundário e se veem impossibilitados de obter emprego adequado ou aceitável, o empreendedorismo pode ser um caminho viável para o êxito econômico" (Halter, 2007:116). A pesquisadora, ao estudar o contexto dos Estados Unidos, identifica habilidades culturais de africanas francófonas que se ocupam de salões de beleza especializados no trançamento de cabelos. "Muitas dessas mulheres ocupavam posições liberais no Senegal, mas chegaram desprovidas das habilidades linguísticas necessárias para ocupar os cargos para os quais foram treinadas ou sequer competir por empregos" (Halter, 2007:117).

Em nossa pesquisa, também localizamos o surgimento de um salão de beleza étnico, além de lojas e pequenos comércios que valorizam elementos culturais como marcadores de diferença e que são responsáveis por uma importante estratégia de inserção no mercado econô- 
mico. Isso ocorre "no marketing de produtos étnicos, na contratação de compatriotas, no relacionamento com clientes co-étnicos, no capital cultural gerado por meio de recursos ou estratégias de capitalização de fundo étnico" (Halter, 2007:117). Neste processo, a apropriação das mídias digitais é importante na articulação dos empreendedores, na divulgação dos produtos e serviços; no contato com outros migrantes e com a população local, como possíveis clientes; e na disseminação da rede de informações e de comunicações construídas a partir dos espaços de negócios étnicos.

Paralelamente às ações de empreendedorismo econômico, e para além das atividades promovidas por associações de caráter político ou religioso, também foi observada a criação de projetos sociais e culturais que buscam aproximar a comunidade migrante da população local e promover atividades culturais - em dinâmicas que identificamos como empreendedorismo social e cultural.

Um destes projetos é o "Senegal, ser negão, ser legal", que surgiu como uma marca criada em Caxias do Sul, por um dos nossos entrevistados, para valorizar a migração senegalesa (que circulava em camisetas vendidas pela internet). O projeto assumiu a dimensão de um coletivo que reúne migrantes e brasileiros em ações como palestras, rodas de conversa em escolas, exposições, mostras culturais e de venda de produtos senegaleses, entre outras.

Apesar das dinâmicas alternativas de inclusão no mercado e de participação social, é necessário que esse fenômeno seja observado de maneira crítica. É o que propõem Zanforlin e Amaral (2019) ao problematizar o empreendedorismo como meio de integração econômica à sociedade que oculta desigualdades, privilegia perfis específicos de migrantes e, muitas vezes, reforça lógicas meritocráticas.

\section{APRENDIZADO FORMAL E INFORMAL}

Como exemplo emblemático de apropriações das tecnologias em rede para aprendizado, citamos o projeto desenvolvido por um de nossos entrevistados, que produz pequenos vídeos a serem compartilhados nas redes sociais online - sobretudo Facebook - para o ensino de português para falantes de wolof. Esta é uma das ações também do projeto "Senegal, ser negão, ser legal", que busca aproximar as culturas do 
Brasil e do Senegal. Outro entrevistado desenvolveu um projeto de curso de wolof para brasileiros, a partir de conteúdo compartilhado em um grupo por whatsapp, e pretende criar um aplicativo, para smartphones, para o ensino desse idioma.

Essas iniciativas mostram a importância do aprendizado do idioma do país de migração para a integração dos sujeitos, inclusive para a inserção no mercado de trabalho formal, e também como forma de participação social e aproximação entre culturas. Os grupos em aplicativos de trocas de mensagens ${ }^{15}$ costumam ser ambiências para o compartilhamento de ofertas de cursos, iniciativas de rodas de conversa e outros eventos, voltados à formação e educação de coletivos migrantes, promovidos por universidades e pela sociedade civil.

\section{COMUNICAÇÃO EM REDE E MÍDIA MIGRANTE}

Além de apropriações individuais das tecnologias de comunicação móvel e da internet, outros sentidos foram identificados na pesquisa na conformação de lógicas midiáticas alternativas através de mídias de migração (Brignol, 2010), entendidas como mídias especializadas, produzidas por e dirigidas prioritariamente a migrantes e que servem de referência informativa e de comunicação. Em especial, entrevistamos seus idealizadores e observamos as rotinas de produção de dois veículos criados e mantidos na rede social online Facebook por migrantes senegaleses: o Sene Brasil TV ${ }^{16}$ e o Touba Brasil TV Rio Grande do Sull ${ }^{17}$.

As duas páginas apresentam lógicas de produção semelhantes. Concentram a maior parte do conteúdo produzido, editado e distribuído, no ambiente online em rede, e o fazem circular entre os migrantes e a população local, conformando dinâmicas de comunicação em redes mais horizontais e de comunicação interativa. Organizados, os migrantes assumem protagonismo na definição de pautas, formas de abordagens e elementos estéticos da composição dos vídeos e fotos. São eles que indicam, a partir da produção midiática em rede, a importância atribuída à comunicação como parte da experiência migratória.

Segundo o idealizador do Touba Brasil TV, o primeiro objetivo do canal é comunicar. Mas também visa criar uma comunicação que, horizontalizada, seja uma ferramenta por meio da qual os migrantes possam ajudar uns aos outros e ampliar suas redes de atuação. O veículo se foca 
na questão religiosa, ainda que esse não seja seu único tema. A ideia é também solucionar dúvidas sobre questões jurídicas aos migrantes (direitos trabalhistas e regularização de documentos, por exemplo) e promover uma intersecção cultural que explique ao brasileiro a cultura senegalesa e vice-versa.

O Touba Brasil TV existe no Brasil em outros estados, como São Paulo e Rio de Janeiro. Para a discussão a respeito do que será publicado, editores de todas as regiões conversam através do WhatsApp. Quando acontecem eventos especiais que demandam coberturas no Rio Grande do Sul, uma estrutura de gravação profissional é contratada pelo canal. Quando não há condições financeiras para a contratação do serviço de filmagem, a cobertura acontece com os próprios celulares, tablets e outras ferramentas tecnológicas acessíveis aos migrantes.

O Sene Brasil TV foca em conteúdos para além da questão religiosa de maneira mais evidente, mas se assemelha ao Touba Brasil TV no que diz respeito à ideia de comunicar aos migrantes sobre as questões fundamentais à sua permanência no Brasil (acerca de documentos, direitos trabalhistas e oportunidades de emprego). Além disso, o Sene Brasil TV tem um perfil mais questionador a respeito dos casos de racismo e preconceito e trabalha na divulgação da cultura senegalesa de forma ampla.

Nos dois casos, percebemos o local central que os usos sociais da mídia ocupam na experiência migratória de construção de narrativas migrantes, muitas vezes, diversas e alternativas àquelas narrativas construídas pela mídia hegemônica. Esta intenção aparece nos relatos dos responsáveis pelo trabalho diário de produção de conteúdo para os canais. De acordo com um dos responsáveis pela Touba Brasil TV em Caxias do Sul:

A comunicação é horizontal e para todo mundo. Mas nossa diferenciação, primeiramente, é a informação exata. Você não pode jogar tudo e ser radical, mas tem que mostrar aquilo que a grande mídia não mostra. Eu estou trabalhando quando a Globo está mostrando o migrante com uma visão que não é verdadeira. Quando eles dizem que todo imigrante é ruim, eu nego. Quando eles dizem que todo migrante é bom, eu nego também. Porque de todas as comunidades do mundo têm pessoas que são ruins e pessoas que são boas. 
Em ambos os canais há uma curadoria feita por migrantes que coletam, avaliam, selecionam e divulgam material de outros canais. Há também um espaço de produção própria (vídeo-reportagens, textos, fotografias, publicações gerais etc.). Esses canais abrem diálogo com outros meios de comunicação, dos quais compartilham conteúdo, assim como com brasileiros e migrantes de outras nacionalidades, construindo diálogos para além da própria comunidade senegalesa.

\section{CIDADANIA MIGRANTE E POLÍTICAS DE POSIÇÃO ANTIRRACISMO}

As mídias também são apropriadas no sentido de tematizar os preconceitos sofridos pela população migrante, relacionados, no caso dos senegaleses, ao racismo e à xenofobia. Isso é percebido nos perfis e páginas em sites de redes sociais online, nas mídias de migração, nos grupos que integram as redes de apoio às migrações e entre outras ambiências midiáticas. Alguns entrevistados apontam que entre as principais diferenças entre o Brasil e o Senegal está o modo como sentem mais fortemente as diferenças sociais atravessadas por questões de classe, raça e etnia no Brasil - sobretudo a partir da percepção das desigualdades entre brancos e negros e nas profundas discriminações nas esferas da justiça, do direito, do trabalho e até do lazer, como observa Schwarcz (2014).

Nas entrevistas iniciais, poucos foram os relatos de experiências concretas de racismo pelos migrantes. Era comum ouvirmos declarações como "os brasileiros apoiam os migrantes" ou "a maioria nos trata bem". Mas aos poucos o tema começou a aparecer de forma mais direta nas entrevistas, nas falas durante as ações promovidas pelas entidades migrantes e em postagens nas redes sociais - especialmente depois de casos de agressões e de morte de migrantes no RS.

A violência também aparece nas ações das prefeituras para impedir a venda ambulante, nas dificuldades de obter vagas no mercado formal, na fala de autoridades ${ }^{18}$, nas restrições da legislação vigente e na ausência de políticas públicas direcionadas a migrantes. Tudo isso faz com que o tema passe a integrar a pauta de reivindicação das associações migrantes. Como reforça o presidente da Associação dos Senegaleses de Porto Alegre, em resposta aos estereótipos construídos em torno da figura dos migrantes: 
Nós somos trabalhadores. Somos pessoas dignas. Somos pessoas educadas. Nada de coisas como ainda estão pensando sobre nós, pensando que nós somos vagabundos, nós somos bandidos, traficantes, nada disso. Somos trabalhadores, pessoas que vêm pra buscar sonhos, sonhadores. Somos seres humanos dignos e educados.

A necessidade de justificar a presença e a existência de uma migração negra, proveniente de um país africano, sobretudo a partir da reivindicação da dignidade pela dimensão do trabalho, indica a manutenção e o aprofundamento do racismo que atravessa as representações das migrações contemporâneas. $\mathrm{O}$ que os senegaleses relatam em suas experiências é a presença de um discurso racializado das diferenças, como bem situa Hall (2010). Baseiam-se em estereótipos que cristalizam o migrante negro a partir de um conjunto de aspectos reducionistas e fixam seus limites na condição de subalternidade. Em parte, a própria valorização do migrante pelo trabalho, mesmo que busque positivar a condição migratória, ajuda a manter uma representação que fundamenta discursos sociais e decisões políticas. Reconhece o sujeito em sua condição de trabalhador apenas tolerado, desde que sempre em situação de provisoriedade, como já denunciava Sayad (1998).

Ao perceber essa condição e reivindicar outras políticas de posição, enquanto sujeitos políticos que se constituem como parte de um país racista, é que os migrantes senegaleses subvertem a ordem e ajudam a construir diferentes formas de representação - papel para o qual as apropriações sociais das mídias e das lógicas da comunicação em rede tornam-se fundamentais.

\section{CONSIDERAÇÕES FINAIS}

Nesse artigo, partindo da discussão teórica que fundamentou a noção de diáspora e de uso social das mídias, aliado ao trabalho de campo com migrantes senegaleses, chegamos a um conjunto de percepções sobre as apropriações das tecnologias e das mídias digitais por migrantes senegaleses em sua experiência de deslocamento no sul do Brasil.

Como resultados, percebemos oito dimensões de usos sociais das mídias por migrantes senegaleses. São elas: a) apropriações relacionadas às famílias e relações transnacionais; b) redes de apoio intra e interculturais; c) associativismo migrante; d) vivência religiosa trans- 
nacional; e) empreendedorismo social e cultural; f) aprendizado formal e informal; g) comunicação em rede e mídia migrante; e h) cidadania migrante e políticas de posição antirracismo.

De modo geral, suas múltiplas apropriações das mídias falam muito sobre o modo como as tecnologias mediam e ajudam a constituir as experiências contemporâneas, ganhando especificidades no caso do contexto migratório transnacional. Os usos sociais das mídias por migrantes senegaleses assumem sentidos táticos de participação social; de construção de narrativas de si (sobretudo nas redes sociais online e nas mídias de migração); de manutenção de vínculos (com a família e amigos no Senegal e com brasileiros); de construção de redes de apoio (mediadas pelas confrarias religiosas e pelas associações migrantes); de ressignificação da experiência diaspórica; e de cidadania migrante.

Ao analisar a mediação das identidades e tecnicidades nas experiências de migrantes senegaleses, foi possível identificar múltiplas lógicas através das quais é reconhecido o papel tático das redes no contexto de migração e a importância da mediação tecnológica para configuração de múltiplos sentidos do que é ser migrante, negro, muçulmano, africano e senegalês no Brasil. Tais dinâmicas enfatizam aspectos relacionais das experiências diaspóricas, em constantes processos de cooperação e conflito que ajudam a construir as culturas migratórias dos coletivos estudados.

O caráter transnacional, próprio das migrações contemporâneas, atravessa vivências religiosas e fundamenta a conformação de relações familiares que se mantém e se ressignificam à distância, pela mediação da tecnologia. No processo, as identidades migrantes são reconfiguradas, exigindo novos posicionamentos dos sujeitos a partir das experiências no local em que estão inseridos. Nesse contexto, as identidades são vividas enquanto narrativas atravessadas pela condição migrante e pelas apropriações das tecnologias das mídias - sobretudo mídias digitais móveis.

A mediação tecnológica na experiência migratória pode ser pensada, também, em termos de competências e de constituição de modos de viver as identidades em diáspora - quer seja nas mídias de migração, na organização de redes de apoio, no aprendizado formal e informal de idiomas ou na disputa por políticas de posição que reivindicam aos migrantes a condição de sujeitos. Os casos observados ao longo 
da pesquisa indicam, ainda, a situação da migração como uma possibilidade para colocar em contato diferenças, evidenciar conflitos e promover encontros que estabeleçam diálogo entre culturas.

(Recebido para publicação em 19 de dezembro de 2018)

(Reapresentado em 26 de abril de 2020)

(Aprovado para publicação em 11 de maio de 2020)

\section{NOTAS}

1. Apoiado pela Fundação de Amparo à Pesquisa do Estado do Rio Grande do Sul (FAPERGS) - Edital no 02/2014, Programa Pesquisador Gaúcho (PqG). Colaboraram com a pesquisa: Nathália Drey Costa, jornalista, doutoranda e mestre em Comunicação pela Universidade Federal de Santa Maria (UFSM); Paola Portella de Bittencourt e Germano Rama Molardi, bolsistas de iniciação científica (Fipe UFSM); e Maritcheli Vieira, mestranda em Comunicação pela UFSM.

2. O nacionalismo metodológico supõe a continuidade de um modelo que busca equiparar estado, sociedade nacional e território, repercutindo nas observações científicas e nos desenhos das pesquisas (Cogo e Brignol, 2015). Segundo Beck (2007), o marco de referência construído a partir do conceito de Estado-nação impede a sociologia de compreender as dinâmicas, os conflitos e as ambivalências das sociedades contemporâneas.

3. Como recupera Patarra (2012), desde a colonização portuguesa, a escravidão como deslocamento forçado que perdurou por mais de três séculos, trouxe cerca de 4 milhões de pessoas retiradas compulsoriamente de países da África e escravizadas. As experiências de migração europeia dirigidas a não portugueses nas primeiras décadas do século XIX, com políticas eugenistas de "branqueamento da população", cunharam uma sociedade escravocrata e com profundas marcas na manutenção do racismo em nossa sociedade.

4. Apesar dos vários vetos feitos pelo então presidente Michel Temer ao texto original, fruto de diversas audiências públicas e com ampla consulta à sociedade civil, a nova lei avança ao reconhecer o migrante, independentemente de sua nacionalidade, como um sujeito dotado de direitos. Ademais, define como princípios da política migratória brasileira a não discriminação e o combate à xenofobia.

5. Disponível em: <http://panoramainternacional.fee.tche.br/?issue=volume-1-numero-3\%2>

6. Instituição mantida pela Congregação Scalabriniana da Igreja Católica em Caxias do Sul, município da Região Norte do RS e que concentra forte presença migratória.

7. Segundo o Instituto Brasileiro de Geografia e Estatística (IBGE), em 2108 esses municípios tinham suas populações estimadas em: 504.069 habitantes em Caixas do Sul; 280.505 habitantes em Santa Maria; e 1.479.101 em Porto Alegre (Fonte: <https:/ / cidades.ibge. gov.br/brasil/rs/panorama>).

8. O Centro Ítalo-brasileiro de Apoio às Migrações (CIBAI-Migrações) é uma entidade mantida por uma congregação da Igreja Católica formada por padres, missionários e leigos scalabrinianos. 
9. Movimento que partiu de instituições voltadas para a defesa de direitos de pessoas em processo de mobilidade, com o objetivo de fomentar e ampliar a rede de acolhimento, atendimento, integração sociocultural, assessoria, informação e de produção de conhecimento sobre a mobilidade humana. Ver: <http:/ / forummobilidaders.wordpress.com/>.

10. Como na reunião da Associação dos Senegaleses de Porto Alegre, em junho de 2015; no $1^{\circ}$ Baile Senegalês, promovido pela Associação dos Senegaleses de Caxias do Sul, em agosto de 2015; na celebração pela visita do líder religioso Ibrahima Khalil Mbacke, em abril de 2016, em Porto Alegre; na festa de promoção da cultura senegalesa em Caxias do Sul (chamada Teranga Brasil), no dia 23 de julho; na festa do Magal de Touba, em 19 de novembro de 2016, nas cidades de Caxias do Sul, Porto Alegre e Santa Maria; e na festa Teranga no Brasil, no dia 23 de julho, em Caxias do Sul.

11. Pelo sistema voip, tecnologia que permite a transmissão de voz por IP (Protocolos de Internet) - a mesma usada em softwares como Skype, Facebook Messenger, Viber e WhatsApp.

12. Como explica Romero, "a Mouridiyya nasceu em meados do século XIX e é a mais recente das confrarias criadas no universo africano islamizado; contudo, é considerada a irmandade religiosa de maior repercussão na África Ocidental e nos contextos diaspóricos dessa organização religiosa na Europa, Estados Unidos, Ásia e América-Latina" (2017:276-277). A confraria Mouride é uma das mais populares no país e foi fundada no século XIX por Cheikh Amadou Bamba.

13. A exemplo do Magal de Touba (ou grande festa da cidade sagrada de Touba, no Senegal), que ocorre simultaneamente em diversas localidades do mundo.

14. O conceito de webdiáspora (Brignol, 2010; Elhajji e Escudero, 2016) está relacionado à criação de ambientes comunicacionais marcados pela lógica do deslocamento e pela vivência em rede da própria diáspora. Incluem-se aí os múltiplos ambientes de comunicação na internet criados, mantidos e atualizados usados por migrantes - que se apropriam da facilidade de acesso à esfera da produção na internet para seus próprios objetivos e demandas.

15. Incluindo o grupo "Senegaleses e Amigos", no aplicativo Whatsapp, que integra brasileiros e migrantes e do que fazemos parte desde o início da pesquisa.

16. Endereço na rede social Facebook: <www.facebook.com/Sene-Brasil-tv-1544172842544055>; e site oficial no endereço <www.senebrasil.com.br>.

17. Endereço da página na rede social Facebook <https://www.facebook.com/profile.ph p?id=100010155188464\&fref $=$ ts $>$.

18. Em entrevista para o jornal O Pioneiro, de Caxias do Sul (4 de abril de 2016), o então prefeito Alceu Barbosa Velho afirmou: "Vem esse bando de imigrantes e temos de dar trabalho e comida?", o que desencadeou uma série de protestos dos migrantes e da comunidade local. Disponível em: <http:/ / pioneiro.clicrbs.com.br/rs/geral/noticia/2016/05/vem-esse-bando-de-imigrantes-e-temos-de-dar-trabalho-e-comida-diz-prefeito-de-caxias-5793331.html>. 


\section{REFERÊNCIAS}

APARICIO, Rosa; TORNOS, Andrés. (2005), Las redes sociales de los inmigrantes extranjeros en España. Madrid: Ministerio de Trabajo y Asuntos Sociales.

APPADURAI, Arjun. (2004), Dimensões culturais da globalização: a modernidade sem peias. Lisboa: Teorema.

BAENINGER, Rosana. (2018), “Introdução”. In: R. Baeninger et al. (orgs.), Migrações Sul-Sul. Campinas: Núcleo de Estudos de População "Elza Berquó” - Nepo/Unicamp.

BECK, Ulrich. (2007), “Vivir en la sociedad del riesgo mundial”. Documentos CIDOB: Dinámicas Interculturales, $\mathrm{n}^{\circ} 8$.

BRIGNOL, Liliane Dutra. (2010), Migrações transnacionais e usos sociais da internet: identidades e cidadania na diáspora latino-americana. Tese (Doutorado em Ciências da Comunicação), Unisinos, São Leopoldo.

. (2015), "Usos sociais das TICs em dinâmicas de transnacionalismo e comunicação migrante em rede: Uma aproximação à diáspora senegalesa no Sul do Brasil". Comunicação Mídia e Consumo [online]. vol. 12, nº 35. [04-06-2018] Disponível em: http:/ / revistacmc. espm.br/index.php/revistacmc/article/view/1099.

; COSTA, Nathália Drey. (2018), "Diáspora senegalesa e mediação tecnológica: entre tempos e lugares na observação do Magal de Touba". Contracampo [online], vol. 37, $n^{\circ}$ 1, pp. 09-29. [12-11-2018] Disponível em http://periodicos.uff.br/contracampo/ article/view/17633/pdf

CAVALCANTI, Leonardo et al. (orgs.). (2015), Relatório Anual 2015. A inserção dos imigrantes no mercado de trabalho brasileiro. Brasília, DF: Observatório das Migrações Internacionais, Ministério do Trabalho e Previdência Social, Conselho Nacional de Imigração e Coordenação Geral de Imigração. Disponível em: <https:/ / portaldeimigracao.mj.gov.br/ images/dados_anuais/relatorio_OBMIGRA_2015_final.pdf>

CAVALCANTI, Leonardo; OLIVEIRA, Tadeu; MACEDO, Marília de. (orgs.). (2018), Relatório Anual 2018. Brasília, DF: Observatório das Migrações Internacionais; Ministério do Trabalho/ Conselho Nacional de Imigração e Coordenação Geral de Imigração. Disponível em: <https://portaldeimigracao.mj.gov.br/images/dados_anuais/RELATORIO_ANUAL_2018.pdf>

CÉSARO, Felipe; ZANINI, Maria Catarina Chitolina. (2017), "Migração senegalesa e mouridismo: um breve exercício interpretativo". In: J. C. Tedesco; G. Kleidermacher (orgs.), A imigração senegalesa no Brasil e na Argentina: múltiplos olhares. Porto Alegre: EST Edições.

CHEVALIER-BEAUMEL, Ellen; MORALES, Orlando G. (2012), “Aproximación etnográfica a la nueva migración africana en Argentina. Circulación y saberes en el caso de los senegaleses arribados en las últimas dos décadas". Astrolabio [online], vol. 1, n 8 , pp. 381-405. [18-09-2015] Disponível em https:/ /revistas.unc.edu.ar/index.php/astrolabio/article/view/583

COGO, Denise. (2012), Latino-americanos em diáspora: usos de mídias e cidadania das migrações transnacionais. Rio de Janeiro: Tríbia.

; BRIGNOL, Liliane Dutra. (2015), “Reposicionando o nacionalismo metodológico: migrações, transnacionalismo e as pesquisas em consumo e recepção”. In: M. Sodré; A. 
C. Temer; M. Elhajji (orgs.), Diásporas urbanas: migrantes, viajantes, transeuntes. Goiânia: Gráfica UFG.

COGO, Denise; ELHAJJI, Mohamed; HUERTAS, Amparo (eds.). (2012), Diásporas, migraciones, tecnologías de la comunicación e identidades transnacionales. Barcelona: Institut de la Comunicació (InCom-UAB).

COGO, Denise; GUTIÉRREZ, Maria; HUERTAS, Amparo (coords.). (2008), Medios de comunicación y migraciones transnacionales: relatos desde Barcelona y Porto Alegre. Madrid: Los Libros de la Catarata.

DE CERTEAU, Michel. (2008), A invenção do cotidiano: artes de fazer. Petrópolis: Vozes.

DIAS, Juliana Braz; LOBO, Andréa de Souza. (2012), "Sobre fluxos e(m) contextos africanos". In: J. B. Dias; A. S. Lobo (orgs.), África em movimento. Brasília: ABA Publicações.

ELHAJJI, Mohamed; ESCUDERO, Camila (2016), “Webdiáspora: migrações, TICs e memória coletiva". Revista Observatório, vol. 2, no 5, pp. 334-363. [03-08-2018] Disponível em: https://sistemas.uft.edu.br/periodicos/index.php/observatorio/article/view/2401

GARCÉS, Alejandro. (2011), “Comercio inmigrante y economías étnicas: síntesis y críticas de los debates vigentes". Polis [online], n 29. [23-08-2018] Disponível em: http://polis. revues.org/1928

GIL, Antonio Carlos. (2008), Métodos e técnicas de pesquisa social. São Paulo: Atlas.

GILROY, Paul. (2007), Entre campos: nações, culturas e o fascínio da raça. São Paulo: Annablume. (2012), O Atlântico Negro: modernidade e dupla consciência. São Paulo/Rio de Janeiro: Editora 34/UCAM - Centro de Estudos Afro-Asiáticos.

GRIMSON, Alejandro. (2001), Comunicación y interculturalidad. Colômbia: Grupo Editorial Norma.

GUBER, Rosana. (2001), La etnografía: método, campo y reflexividad. Buenos Aires: Grupo Editorial Norma.

HAHN, Hans Peter; KLUTE, Georg. (2007), “Cultures of migration: introduction”. In: H. P. Hahn; G. Klute (orgs.), Cultures of migration: African perspectives. Berlin: LIT.

HALL, Stuart. (1996), "Identidade cultural e diáspora”. Revista do Patrimônio Histórico e Artístico Nacional - IPHAN [online], $\mathrm{n}^{\circ}$ 24, pp. 68-75.

. (2003), Da diáspora: identidades e mediações culturais. Belo Horizonte/Brasília: Editora UFMG/UNESCO.

(2010), "El espectáculo del otro". In: Sin garantías: trayectorias y problemáticas en estudios culturales. Lima, Bogotá, Quito: Instituto de Estudios Sociales y Culturales Pensar, Universidad Javeriana Instituto de Estudios Peruanos Universidad Andina Simón Bolívar, Ecuador Envión Editores.

HALTER, Marylin. (2007), “Cultura econômica do empreendimento étnico: caminhos da imigração ao empreendedorismo". RAE [online], vol. 47, $\mathrm{n}^{\circ} 1$. [10-08-2018] Disponível em: http://www.scielo.br/scielo.php?script=sci_arttext\&pid=S0034-75902007000100008 
HEIL, Tilmann. (2018), "Uma infraestrutura muçulmana de chegada no Rio de Janeiro". REMHU [online], vol. 26, no 52, pp. 111-129. [25-04-2020] Disponível em: http:/ /www. scielo.br/scielo.php?pid=S1980-85852018000100111\&script=sci_abstract\&tlng=pt

HERÉDIA, Vania (org.). (2015), Migrações internacionais: o caso dos senegaleses no Sul do Brasil. Caxias do Sul: Belas Letras.

HERÉDIA, Vania; GONÇALVES, Maria do Carmo. (2017), “Experiências migratórias: uma imigração sem mulheres". In: Seminário Internacional Fazendo Gênero 11 e 13th Women's Worlds Congress (Anais Eletrônicos). [15-08-2018] Disponível em: <http://www. en.wwc2017.eventos.dype.com.br/resources/anais/1498784755_ARQUIVO_TextoCompletoVaniaHerediaMariaCarmoGoncalves.pdf $>$.

HERÉDIA, Vania; PANDOLFI, Bruna. (2015), “Migrações internacionais: o caso dos senegaleses em Caxias do Sul”. In: V. B. Herédia (org.), Migrações internacionais: o caso dos senegaleses no Sul do Brasil. Caxias do Sul: Belas Letras.

HERRERA, Gioconda. (2004), “Elementos para una comprensión de las famílias transnacionales desde la experiencia migratoria del Sur del Ecuador". In: F. Hidalgo (ed.), Migraciones: un juego con cartas marcadas. Quito: ILDISAbya, pp. 215-231.

HINE, Christine. (2015), Ethnography for the internet: embedded, embodied and everyday. Huntington, GBR: Bloomsbury Publishing.

KANDEL, William; MASSEY, Douglas. (2002), "The culture of mexican migration: A theoretical and empirical analisys". Social Forces [online], vol. 80, n 3, pp. 981-1004. Disponível em: https://pubag.nal.usda.gov/download/38751/PDF

KLEIDERMACHER, Gisele. (2013), “Entre cofradías y venta ambulante: una caracterización de la inmigración senegalesa en Buenos Aires". Cuadernos de Antropología Social [online], no 38, pp. 109-130. [15-08-2018] Disponível em http:/ / www.scielo.org.ar/scielo. php?script=sci_arttext\&pid=S1850-275X2013000200005

MAESTRO, Susana Moreno. (2006), Aquí y allí, viviendo en lós dos lados. Los senegaleses de Sevilla, una comunidad transnacional. Sevilha: Estudios Monográficos.

MAMADOU, Alfa Diallo. (2011), A construção do Estado no Senegal e integração na África Ocidental: os problemas da Gâmbia, de Casamance e da integração regional. Dissertação (Mestrado em Ciência Política). Universidade Federal do Rio Grande do Sul, Porto Alegre.

MARTÍN-BARBERO, Jesús. (2001), Dos meios às mediações: comunicação, cultura e hegemonia. Rio de Janeiro: Editora UFRJ.

. (2002), Oficio de cartógrafo: travesías latinoamericanas de la comunicación en la cultura. Santiago de Chile: Fondo de Cultura Económica.

. (2006), "Tecnicidades, identidades, alteridades: mudanças e opacidades da comunicação no novo século". In: D. Moraes (org.), Sociedade midiatizada. Rio de Janeiro: Mauad, pp. 51-79.

(2014), “Diversidade em convergência”. Matrizes, vol. 8, n² 2. Disponível em: < https:// www.revistas.usp.br/matrizes/article/view/90445>. 
(2015), "Desde dónde pensamos la comunicación hoy". Chasqui [online], n 128, pp. 13-29. Disponível em: <https://revistachasqui.org/index.php/chasqui/article/view/2545>

; BERKIN, Sarah Corona. (2017), Ver con los otros: comunicación intercultural. Ciudad de México: Fondo de Cultura Económica.

MORALES, Orlando Gabriel; KLEIDERMACHER, Gisele. (2015), “Representaciones de migrantes senegaleses en la sociedad porteña de Buenos Aires: apuntes sobre exotismo y exotización". Etnográfica [online], vol. 19, n 1, pp. 29-50. Disponível em: <http:// etnografica.revues.org/3884>

MOUTINHO, Laura. (2014), “Diferenças e desigualdades negociadas: raça, sexualidade e gênero em produções acadêmicas recentes". Cadernos Pagu [online], nº 42, pp. 201-248. Disponível em <https: / /www.scielo.br/pdf/cpa/n42/0104-8333-cpa-42-00201.pdf>

ORTIZ, Renato. (2015), Universalismo e diversidade. São Paulo: Boitempo.

PASCUAL DE SANS, Àngels (org.). (2007), Redes sociales de apoyo: la inserción de la población extranjera. Bilbao: Fundación BBVA.

PATARRA, Neide Lopes. (2012), “O Brasil: país de migração?”. E-metropolis [online], nº 9, pp 6-18. Disponível em: <http:/ / emetropolis.net/artigo/64?name=o-brasil-pais-de-imigracao $>$.

PEDONE, Claudia. (2007), "Familias transnacionales ecuatorianas: estrategias productivas y reproductivas". In: V. Bretón et al. (orgs.), Ciudadanía y exclusión: Ecuador y España frente al espejo. Madrid: Catarata, pp. 251-278.

PEIXOTO, Fernanda Arêas. (2018), "Relembrar Michel de Certeau”. Revista de Antropologia [online], vol. 61, n² 2, pp. 96-109. Disponível em: <http://www.revistas.usp.br/ra/ article/view/148937>.

PEÑARANDA CÓLERA, Maria Carmen. (2005), "El locutorio como espacio social transnacional: una mirada psicosocial". Athenea Digital, nº 8, pp. 454-460. Disponível em: $<$ https: / / www.redalyc.org/articulo.oa?id=53700839>.

PORTES, Alejandro. (1997), Globalization from below: the rise of transnational communities. Princeton University.

ROMERO, Fanny Longa. (2017), "Islã, parentesco e ritual na irmandade religiosa Mouridiyya: percursos da etnografia no contexto da imigração de africanos senegaleses no Brasil". In: J. C. Tedesco; G. Kleidermacher (orgs.), A imigração senegalesa no Brasil e na Argentina: múltiplos olhares. Porto Alegre: EST Edições.

ROSSA, Juliana. (2017), "Poética vocal religiosa de imigrantes senegaleses mourides em Caxias do Sul - RS”. In: J. C. Tedesco; G. Kleidermacher (orgs.), A imigração senegalesa no Brasil e na Argentina: múltiplos olhares. Porto Alegre: EST Edições.

SAKHO, Pape; DIAGNE, Abdoulaye; SAMBOU, Pierre Corneille. (2017), "Le bassin arachidier, Du réceptacle de flux internes au foyer d'emigration interne at internationale". In: J. C. Tedesco; G. Kleidermacher (orgs.), A imigração senegalesa no Brasil e na Argentina: múltiplos olhares. Porto Alegre: EST Edições. 
SAKHO, Pape et al. (2015), "A emigração internacional senegalesa". In: V. B. M. Herédia (org.), Migrações internacionais: o caso dos senegaleses no Sul do Brasil. Caxias do Sul: Belas Letras.

SAYAD, Abmalek. (1998), Imigração ou os paradoxos da alteridade. São Paulo: EDUSP.

SCHWARCZ, Lilia Moritz. (2014), Nem preto, nem branco, muito pelo contrário. São Paulo: Claro Enigma.

SOLÉ, Carlota; PARELLA, Sónia. (2005), Negocios étnicos. Los comercios de los inmigrantes no comunitários en Cataluña. Barcelona: CIDOB.

TEDESCO, João Carlos. (2017), “Apresentação”. In: J. C. Tedesco; G. Kleidermacher (orgs.), A imigração senegalesa no Brasil e na Argentina: múltiplos olhares. Porto Alegre: EST Edições.

TRUZZI, Oswaldo. (2008), "Exploring the concept of networks in migration processes". Tempo Social [online], vol. 20, $\mathrm{n}^{\circ}$ 1, pp.199-218. Disponível em: <http:/ /dx.doi.org/10.1590/ S0103-20702008000100010>.

UEBEL, Roberto Rodolfo Georg. (2018), “Dinâmicas migratórias e transfronteirizações na Bacia do Prata: um olhar sobre a migração transnacional de haitianos e senegaleses". In: R. Baeninger et al. (orgs.), Migrações Sul-Sul. Campinas: Núcleo de Estudos de População "Elza Berquó" - Nepo/Unicamp.

VISENTINI, Paulo Fagundes; RIBEIRO, Luiz Dario; PEREIRA, Analúcia Danilevicz. (2014), História da África e dos africanos. Petrópolis: Vozes.

ZANFORLIN, Sofia Cavalcanti; AMARAL, Renata Maria do. (2019), “Empreendedorismo para migrantes". E-Compós, vol. 22, n 1, Disponível em: <https://doi.org/10.30962/ ec.1647>. 


\section{RESUMO}

Tecnicidades e Identidades Migrantes nos Usos Sociais das Mídias: Uma Aproximação à Diáspora Senegalesa no Sul do Brasil

$\mathrm{O}$ artigo discute como as mediações das identidades e tecnicidades atravessam experiências migrantes de usos sociais das mídias, especialmente das mídias digitais e em rede. Parte de uma revisão teórica sobre as noções de identidades em diáspora, e da perspectiva das mediações, para fundamentar a análise sobre apropriações midiáticas por migrantes senegaleses no Rio Grande do Sul. As estratégias metodológicas são construídas a partir da inserção em um campo de investigação complexo e multissituado que abarca dinâmicas de comunicação construídas de modo transnacional, em práticas e processos de comunicação que se dão entre as instâncias online e offline. Como resultados, percebe-se que os múltiplos usos sociais das mídias por migrantes senegaleses assumem sentidos táticos de participação social, construção de narrativas de si, manutenção de vínculos, construção de redes de apoio, ressignificação da experiência diaspórica e de cidadania migrante, com destaque a políticas antirracistas.

Palavras-chave: migrações; usos sociais das mídias; mediações; comunicação em rede; Senegal

\section{ABSTRACT \\ Techniques and Migrant Identities in the Social Uses of the Media: An Approach to the Senegalese Diaspora in Southern Brazil}

This article discusses how the mediation of identities and technical qualities cross migrant experiences of social uses of media, especially digital and network media. The text starts from a theoretical review on notions of identities in Diaspora and from the perspective of mediations to support the analysis of media appropriations by Senegalese migrants in Rio Grande do Sul. The methodological strategies are established from the insertion in a complex and multi-situated research field that embraces communication dynamics built in a transnational way, through communication practices and processes that take place between online and offline instances. As a result, it is clear that the multiple social uses of media by Senegalese migrants assume tactical meanings of social participation, building self-narratives, maintaining links, creating support networks, redefining the diasporic experience and migrant citizenship, with an emphasis on anti-racist policies.

Keywords: migrations; social uses of media; mediations; network communication; Senegal 


\section{RÉSUMÉ}

Techniques et Identités des Migrants dans les Usages Sociaux des Médias: Une Approche de la Diaspora Sénégalaise du Sud du Brésil

L'article explique comment les médiations des identités et des aspects techniques traversent les expériences des migrants en matière d'utilisation sociale des médias, en particulier des médias numériques et en réseau. On part d'une révision théorique sur les notions d'identités en diaspora, et dans la perspective des médiations, pour soutenir l'analyse des appropriations médiatiques par les migrants sénégalais du Rio Grande do Sul. Les stratégies méthodologiques sont construites à partir de l'insertion dans un champ de recherche complexe et multisitué qui englobe les dynamiques de communication construites de manière transnationale, dans les pratiques et processus de communication qui ont lieu entre les instances en ligne et hors ligne. En conséquence, il est clair que les multiples utilisations sociales des médias par les migrants sénégalais assument des significations tactiques de participation sociale, de construction d'auto-récits, de maintien de liens, de création de réseaux de soutien, de redéfinition de l'expérience diasporique et de citoyenneté des migrants, en mettant l'accent sur les politiques racistes.

Mots-clés: migrations; utilisations sociales des médias; médiations; communication en réseau; Sénégal

\section{RESUMEN}

Tecnicismos e Identidades Migrantes en los Usos Sociales de los Medios de Comunicación: Una Aproximación a la Diáspora Senegalesa en el Sur de Brasil

El artículo discute cómo las mediaciones de las identidades y tecnicismos atraviesan experiencias migrantes de los usos sociales de los medios, especialmente de los medios digitales y en red. Se parte de una revisión teórica sobre las nociones de identidades en diáspora y de la perspectiva de las mediaciones, para fundamentar el análisis sobre apropiaciones mediáticas por migrantes senegaleses en Rio Grande del Sur. Las estrategias metodológicas son construidas a partir de la inserción en un campo de investigación complejo y multisituado que abarca dinámicas de comunicación construidas de modo transnacional, en prácticas y procesos de comunicación que se dan entre instancias online y offline. Como resultados, se percibe que los múltiples usos sociales de los medios de comunicación por migrantes senegaleses asumen sentidos tácticos de participación social, construcción de auto narrativas, mantenimiento de vínculos, construcción de redes de apoyo, resignificación de la experiencia de diáspora y de ciudadanía migrante, especialmente en políticas antirracistas.

Palabras clave: migraciones; usos sociales de los medios de comunicación; mediaciones; comunicación en red; Senegal 